\title{
A tragedy tailored to the spirit of the times - Romeo and Juliet as interpreted by Franco Zeffirelli and Baz Luhrmann
}

\author{
ANNA ŚLIWIŃSKA \\ Institute of Film, Media and Audiovisual Arts \\ Adam Mickiewicz University, Poznań, Poland
}

\begin{abstract}
Anna, A tragedy tailored to the spirit of the times - Romeo and Juliet as interpreted by Franco Zeffirelli and Baz Luhrmann. „Images” vol. XXVI, no 35. Poznań 2019. Adam Mickiewicz University Press. Pp. 219-229. ISSN 1731-450X. DOI 10.14746/i.2019.35.12.

This article discusses two film adaptations of Romeo and Juliet, i.e. one directed by Franco Zeffirelli and the other by Baz Luhrmann. It covers the following aspects: the structure of both the drama and its two film adaptations, the characters' creation, the choice of setting and screen time, and the function of tragedy. Shakespeare's language is characterised by unparalleled wit and powers of observation, and the final form of his plays is a clear indication of his ambivalent attitude towards tradition and the rigid structure of the drama. By breaking with convention, favouring an episodic structure, and blending tragedy with comedy, Shakespeare always takes risks, in a similar vain to the two directors who decided to make film adaptations based on his plays. Each technical device the adaptors selected could have turned out to be a wonderful novelty or a total disaster. The strength of both Zeffirelli's and Luhrman's adaptations is their emphasis on love and youth, which thanks to their directorial skill is perfectly in tune with the spirit of their respective times.
\end{abstract}

KEYwORDs: Romeo and Juliet, William Shakespeare, film adaptation, tragedy, Franco Zeffirelli, Baz Luhrmann

Alongside Hamlet, Romeo and Juliet remains the most popular and most commonly adapted of Shakespeare's plays. Before 1939 there had been already over a dozen film adaptations of this work. According to Marek Hendrykowski[1], in 1908 alone as many as three films were made of this play, i.e. an Italian production by Mario Caserini, an American one by Stuart Blackton and a British one produced by the Gaumont-British Picture Corporation. The list of film adaptations can obviously be much longer and the productions most commonly referred to include: George Cukor's (1936), Renato Castellani's (1954), Franco Zeffirelli’s (1968, Romeo and Juliet) and Baz Luhrmann's film William Shakespeare's Romeo + Juliet (1996). Despite being made almost thirty years apart, Zeffirelli's and Luhrmann's films share a common intention to inteprate Shakespeare's play, i.e. to make a film about and for a young audience[2]. According to Patricia Tatspaugh, Zeffirelli's adaptation targeted the younger generation of Americans protesting against the Vietnam War who, to use Sarah Munson Deats' words, stood in opposition to their parents' ideals of military prestige and the use of force. Tatspaugh emphasises the fact that both Zeffirelli's and Luhr-

[1] As quoted by: P. Zakens, Szekspirowanie po ekranie [Shakespearean screen], [in:] Szkice z poetyki filmu [Essays on film poetics], ed. M. Hendrykowski, Poznań 1995, p. 49.

[2] Both Cukor and Castellani made their adaptations following the rules of traditional filming, which in fact frequently fails when applied to Shakespeare's works. It is the kind of filming that is usually accused of having an excessively theatre-like appearance, in the worst sense of the word. Its mainfeatures include: scarce frames filmed on location, excessive exposure of interiors, a monotonous soundtrack and, finally, poor casting, where the greatest sin lay in selecting actors far too mature to play the young lovers, Romeo and Juliet. 
mann's adaptations, while so distinctively different, convey the same ironic commentary on the generation gap [3]. Romeo and Juliet is one of Shakespeare's earliest plays[4]; it was Zeffirelli's second encounter with a Shakespeare work and Baz Luhrmann made his William Shakespeare's Romeo + Juliet straight after his debut production, 1992's Strictly Ballroom. What is present in all these titles is a certain aura of freshness and youthfulness, i.e. the first strokes of the playwright's quill and the filmmaker's freedom to intepret a canonical piece of literature. These film adaptations share a comprehensive understanding of Shakespeare's intentions, which does not necessarily mean blindly mimicking the master, but instead reflects an informed intuition in following the amplitude of emotions that accompanied the process of working on this piece. Particular elements of these adaptations, such as their structure, character creation, choice of the setting and the screen time and the function of tragedy, provide evidence of the application of radically distinct means of expression can lead to the same ability to convey a very Shakespearean version of Romeo and Juliet.

[3] P. Tatspaugh, The Tragedies of Love on Film, [in:] The Cambridge Companion to Shakespeare on Film, ed. R. Jackson, Cambridge 2000, p. 140. [4] Fallacious Shakespeare biographies dealing with the period before he wrote Romeo and Juliet are presented in the phenomenal feature film Shakespeare in Love and a more recent BBC TV series Upstart Crow. In both of them, the screenwriters emphasise that Shakespeare's main sources of inspiration came from his own experiences, from his social milieu, and that at times he pilfered ideas from other writers.

[5] The Merchant of Venice is arguably the only exception to this rule. However, due to the comedy formula, the moneylender does not in the end become a tragic figure. E. Auerbach, Mimesis, The Representation of Reality in Western Literature, Princeton 2003, p. 314.

[6] S.T. Coleridge, Coleridge's Lectures On Shakespeare and Other Poets and Dramatists. The Seventh Lecture, ed. by Ernest Rhys, London 1914, p. 425 .

\section{Structure}

Shakespeare's tragedy opens with a Prologue delivered by the Chorus, which represents the legacy of the ancient Greek theatre tradition. The play is composed of 5 acts. Acts One, Three and Four contain 5 scenes, Act Two six scenes and Act Five is composed of three scenes. Elizabethan drama broke with classical rules, e.g. the unity of time and setting. It rejected the rigid form of traditional composition and aesthetic uniformity. Instead, it offered a loose and episodic plot structure, which on many occasions gave room for the psychological dimension of the characters. Shakespeare makes deliberate and conscious selections from both traditional theatre and more contemporary trends, following the rule of what best fits in with his needs.

Alongside the Chorus, the legacy of ancient drama in Shakespeare's works also includes what Erich Auerbach emphasises as the choice of tragic characters with a noble background [5] Nevertheless, it is worth remembering that Shakespeare's apt and precise language makes it possible for him to describe with equal ease the lives of characters that come from all walks of life. As Samuel Taylor Coleridge asks rhetorically:

On the other hand, look at Shakespeare: where can any character be produced that does not speak the language of nature? Where does he not put into the mouths of his dramatis personae, be they high or low, Kings or Constables, precisely what they must have said? Where, from observation, could he learn the language proper to Sovereigns, Queens, Noblemen or Generals? Yet he invariably uses it.[6]

The ancient tradition of prologue and epilogue that encapsulate the world within clear-cut, well-defined boundaries also found its counterparts in film adaptations of Shakespeare's works. In Zeffirelli's production, they were delivered in the form of a voiceover, which made them compatible from the compositional point of view with the first and the last scene of the film. In William Shakespeare's Romeo + Juliet, the words of the Prologue and Epilogue come from a female journalist on a TV news programme. As the Epilogue comes to an end, 
the image on TV starts fading and the screen starts to drift away into darkness until it disappears completely. In Shakespeare's play, the final comment on the tragedy is delivered by the Prince, who says:

\footnotetext{
A glooming peace this morning with it brings,

The Sun for sorrow will not show his head:

Go hence to have more talk of these sad things

Some shall be pardon'd, and some punished.

For never was a story of more woe,

Than this of Juliet and her Romeo.[7] [Act V.3: p. 138]
}

In Zeffirelli's film, these words coincide with an image of the newly reconciled enemies. Luhrmann, on the other hand, added a contemporary context to the Epilogue, which is addressed directly to the audience[8]. The boldness of the verbal message is enhanced by the image of a disappearing TV screen, which constitutes an ironic commentary on our times. In managing to save their love, Romeo and Juliet were victorious over a world full of hate and confused values. It is the viewer who loses, as they are left with an empty screen, just like on any other day when the news, saturated with human tragedies, is over.

According to Patricia Tatspaugh, Zeffirelli retained 35 percent of Shakespeare's original text, in order to focus on the main elements of the story and the main characters[9]. Both his and Luhrmann's adaptation follow the sequence of scenes contained in Shakespeare's original. Only once does Zeffirelli change Shakespeare's: the film first shows Juliet finding out that Romeo has killed Tybald, and only afterwards do we see Mrs Capulet grieving over the body of her nephew, as the Prince reads out the decree sentencing Romeo to exile. Thanks to this trick of swapping the two scenes over, and despite considerable cuts in the original text, the sense of cohesion is retained.

In Luhrmann's adaptation, many scenes and a significant part of the original text are cut. The video-clip style of storytelling allows for a laconic and free approach to Shakespeare's original. There are two instances in the film where short shots not integrated in the whole suggest to the viewer how the story is going to develop. The words of Friar Laurence regarding the poison are accompanied with a frame showing Juliet, who has already taken it. The frame, divided into two, blends Friar Laurence's story with the image of the sleeping Juliet, which in turn highlights the couple's determination and the inevitability of their fate. Another example of an unintegrated shot that defies the coherence of the scene is that showing Romeo before setting off for the ball, as he says:

I fear too early, for my mind misgives

Some consequence yet hanging in the stars

Shall bitterly begin his fearful date

With this night's revels, and expire the term

Of a despisèd life closed in my breast

By some vile forfeit of untimely death.

But he that hath the steerage of my course,

Direct my sail. On, lusty gentlemen! [10][ Act I.4: pp. 50-51]

His words were accompanied with the image of the young man entering Juliet's tomb (the same image was once again screened at the end of the film). With this visualisation of Shakespeare's message, the director suggests that the young couple's fate was sealed before they even met.

According to Henryk Zbierski, the structure of Romeo and Juliet can be seen as divided into two parts, with the boundary marked by the first scene of Act 3. Up to that point, the reader is only offered the background to the story, whereas the plot unfolds in earnest only in the second part of the play[11]. The same design is noticeable in the two film adaptations

[7] W. Shakespeare, Romeo and Juliet, Act V.3, 1994 London, p. 138.

[8]It has to be remembered that this type of direct address also features in other Shakespeare plays, e.g. in monologues by Puck and Prospero.

[9] P. Tatspaugh, op.cit., p. 141.

[10] W. Shakespeare, op.cit., Act I.4: pp. 50-51.

[11] H. Zbierski, Droga do Werony. Studium historycznoliterackie. „Romeo i Julia” Szekspira [En route to Verona: historical and literaty study of Shakespeare's Romeo and Juliet], Poznań 1966, p. 321. 
discussed here, where in both cases, the scene of Mercutio's death is the pivotal point, albeit filmed quite differently. Zeffirelli puts the scene right in the middle of his film and expands it with long shots of the fight. Described in Shakespeare's original with the briefest of directions “They fight", in Zeffirelli's work it is extended to a duel lasting several minutes[12]. The chaos of this scene is further intensified by enormous dust clouds.

Elements of nature frequently reflect the emotional state of Shakespeare's characters (e.g. Macbeth). Although not mentioned in the original text of the play, the wind that accompanies the scene of Mercutio's death in Luhrmann's film is there to enhance the drama, with him dying in the manner of a stage actor. The impression is further intensified by the fact that Luhrmann selects a different setting for

[12] It is an obvious trick, yet one that prolongs the scene at the same time. It is used again in Zeffirelli's film in Act One, Scene One, where the original "They fight" becomes a trigger for another scene of fight. This time it is not only between the two feuding families, but those who happen to find themselves in the Verona street. Luhrmann moves this scene to the petrol station and its structure evokes various intertextual connotations. One of them is the Western convention, or references to Alfred Hitchcock's Birds (S.M. Buhler, Shakespeare in the Cinema, Ocular Proof, New York 2002, p. 90). It is clear that the whole film is abundant in references to various film genres. Alicja Helman calls it an adaptation "made up as a gangster drama" (A. Helman, Przemoc i nostalgia $w$ filmie gangsterskim [Violence and nostalgia in the gangster film], [in:] Kino gatunków wczoraj i dziś [Genre cinema now and in the past], K. Loska (ed.), Kraków 1998, p. 24). Grażyna Stachówna puts it in the context of melodrama (G. Stachówna, O melodramacie filmowym [On film melodrama], [in:] Kino gatunków wczoraj i dziś [Genre cinema now and in the past], ed. K. Loska, Kraków 1998, p. 37) and the director himself mentions references to the 1940 s and 1970 s cinema (SW, Kochankowie $z$ Verona Beach, op.cit., p.44.).

[13] W. Shakespeare, Macbeth, Cambridge 1925, pp. $81-82$. the scene. He moves it to the Sycamore Grove, which in his interpretation turns out to be the ruins of an old theatre on an empty beach. This way Luhrmann lends the scene of Mercutio's death a visual paraphrase of the famous lines from Macbeth:

\footnotetext{
Life's but a walking shadow, a poor player That struts and frets his hour upon the stage And then is heard no more. It is a tale Told by an idiot, full of sound and fury, Signifying nothing. [13]
}

\section{Characters}

Numerous Shakespeare specialists reiterate a well-known truth about his plays, i.e. the most comprehensive effect of a theatrical piece of art stems from the juxtaposition of "filled-out" with "flat" characters, in other words, those that are more complex with those of a simple design, the exaggerated with the balanced, the comical with the serious, those with rhetorical skill and those using very simple language. The character design in Romeo and Juliet serves as a perfect example of this rule. The lead characters are in fact one-dimensional and less attractive to the reader when compared to the exuberant and witty supporting characters, who sparkle with humour.

It is not justifiable to follow the usual path of interpretation, which identifies Romeo as an immature, amorous youth, and Juliet as a romantic "lamb". Their conversations in fact reflect the true nature of their respective characters. While Romeo's language is replete with references to the sky and the stars, and where love is defined as a glow of light, Juliet's words are far more rooted in reality. She comes across as a down-to-earth girl and she is the one who sets all the rules, including the meeting and the wedding date.

The couple is probably best characterised by the famous balcony scene of Act Two, Scene Two. This is the point at which Shakespeare presents Romeo as somebody who believes in the ideal of love. He is led to the Capulet ball to find the ideal object of his desires, Rosaline. However, later on Romeo declares: 
With Rosaline, my ghostly father no,

I have forgot that name, and that name's woe. [14]

[Act II.3: p. 67]

The new ideal love and object of Romeo's affections turns out to be the daughter of the rival house, but it is her eyes that he now compares to stars and she is now his light. Juliet's replies to the beloved's affectionate declarations are pragmatic and down-to-earth. This is exactly how the two adaptations discussed here interpret Shakespeare's couple. In Zeffirelli's adaptation, created in the spirit of Flower Power, Romeo's question: "O wilt thou leave me so unsatisfied?" is followed by Juliet replying with a mischievous smile: "What satisfaction canst thou have to-night?"[15] [Act II.2: 63]. The same kind of Juliet is featured in Luhrmann's production in the swimming pool scene (which stands for the balcony), where she reacts to Romeo's line on the human flesh [16] with a cheekily ribald expression on her face.

In Shakespeare's play, Juliet "[...] is nearing her fourteenth birthday. Since Renaissance physiologists generally considered fourteenth to mark the beginning of puberty [...] Shakespeare apparently intended to picture Juliet's love for Romeo as first love, strengthened by the fact that she is just becoming emotionally aware of the meaning of love itself." [17]

Olivia Hussey, the actress playing Juliet in Zeffirelli's adaptation, is equally young, innocent and shy. She blushes the moment she decides to declare her love for Romeo ("Thou know'st the mask of night is on my face, Else would a maiden blush bepaint my cheek, For that which thou hast heard me speak to-night" [18] [Act II.2: p. 61]). Luhrmann's Juliet, played by Claire Danes, is energetic and akin to more upto-date models of womanhood[19]. The director does not emphasize her young age, but instead her practical common sense and vitality, which stands in contrast to Romeo's features (played by Leonardo DiCaprio). In Luhrmann's adaptation, Romeo has yet another feature that the Shakespeare's prototype does not, i.e. he is particularly clumsy, which again provides a striking contrast to Juliet's resourcefulness. He keeps tripping wherever he goes, which is reflected in Friar Laurence's commentary: "Wisely and slow, they stumble that run fast" [20] [Act II.3: p. 68].

Luhrmann's Romeo is exceedingly romantic and very unpragmatic, just as Zeffirelli interpreted this character, in this case played by Leonard Whiting. According to Russell Jackson, Zeffirelli's Romeo additionally carries the added value of classical Renaissance beauty interpreted anew in the context of 1960s' culture[21].

It is worth mentioning at this point that $\mathrm{Ze}$ ffirelli's Romeo and Juliet is the first adaptation that puts so much emphasis on the youthfulness and vitality of Shakespeare's main characters. This feature is most clearly evident in the ball scene, where the minstrel sings What Is a Youth (with new lyrics, the song became a hit worldwide under the title A Time for Us[22]):

What is a youth? Impetuous fire.

What is a maid? Ice and desire.

The world wags on,

A rose will bloom

It then will fade,

So does a youth,

So does the fairest maid.[23]

According to Coleridge, Romeo and Juliet are both the type of Shakespearean characters whose vividness could only be achieved on

[14] W. Shakespeare, Romeo and Juliet, Act II.3: p. 67 .

[15] Ibidem, Act II.2: p. 63.

[16] Ibidem, p. 57.

[17] J.E. Hankins, Introduction, [in:] W. Shakespeare, Romeo and Juliet, New York, London 1970, p. 18.

[18] W. Shakespeare, Romeo and Juliet, Act II.2: p. 61.

[19] Light-hearted mocking, but at times very apt observation on the attitute towards women in Shakespearean times can be found in the Upstart Crow TV series.

[20] W. Shakespeare, Romeo and Juliet, Act II.3: p. 68.

[21] R. Jackson, Shakespeare and the English Speaking Cinema, Oxford 2014, p. 88.

[22] S.M. Buhler, op.cit., p. 91.

[23] The quote comes from Zeffirelli's film soundtrack. 
stage, in contrast to Mercutio and the Nurse, whose literary lines appeal to the reader immediately. Coleridge compares Mercutio to Shakespeare himself:

Mercutio is a man possessing all the elements of a poet. The whole world was, as it were, subject to his law of association. Whenever he wishes to impress anything, all things become his servants for the purpose, all things tell the same tale, and sound in unison[24].

Mercutio can be seen as a perfect complement to Romeo. He is both intelligent and, at the same time, almost oblivious to his great intellect, obscene and amusing, but most of all, witty. And the Nurse?

Thus, in the Nurse you have all the garrulity of old age, and all its fondness; for the affection of oldage is one of the greatest consolations of humanity. [...] You have also in the Nurse the arrogance of ignorance, with the pride of meanness at being connected with a great family. You have the grossness, too, which that situation never removes, though it sometimes suspends it; and, arising from that grossness, the little low vices attendant upon it, which, indeed, in such minds are scarcely vices[25].

The Nurse is the opposite of Mercutio. She is somewhat dull and her world is limited only to the images connected through her own associations, i.e. hers is a world where it is impossible to find cause-effect relations.

Such perfectly designed characters are particularly hard to interpret and incorporate into a film. This is exactly where the weakest link in Zeffirelli's adaptation can be identified. There is no reason to criticise the Nurse, played by Pat Heywood. However, Mercutio, as played by John McEnery, justifies a fair share of crit-

[24] S.T. Coleridge, op.cit., p. 422.

[25] Ibidem, pp. 423-424.

[26] The author argues in favour of John McEnery's acting skills for creating a very vibrant character in this film. P. Tatspaugh, op.cit., p. 141. [27] W. Shakespeare, Romeo and Juliet, Act III.1: p. 83 .

[28] The author argues that this is exactly how Mercutio in Zeffirelli's film has been interpreted numerous times, Cf. Tatspaugh, op.cit., p. 141. icism, although this should not be levelled at the acting itself[26], but rather the design of this film character. Zeffirelli presents Mercutio as a jester and cuts his lines to the minimum, as a result of which Mercutio's wit and intellect cannot be fully appreciated. On the other hand, Zeffirelli enriches his adaptation with a number of slapstick comedy elements, through which Mercutio comes across as the central figure of the farce and clowning around. Heavy-handed joking and obscene gestures are all that remain of one of the best-designed characters in Romeo and Juliet.

In Shakespeare's play Mercutio's death resounds with comic effect encapsulated in the lines which, paradoxically, enhance the tragedy of the situation: "[...] ask for me tomorrow and you shall find me a grave man" [27] [Act III.1: p. 83]. Unfortunately, Zeffirelli does not manage to maintain this balance, i.e. the laughter is too loud and it lasts too long. The film incarnation of Mercutio dies the death of a jester, in line with his role in the film.

In Luhrmann's adaptation, Mercutio, played by Harold Perrineau, comes across as the very essence of the Shakespeare character, further enhanced with a more contemporary feel. In fact, Mercutio is the most versatile character designed by Luhrmann in his adaptation. He is capable of joking, even in quite a vulgar manner, but at the same time, he maintains his seriousness, for instance, in his monologue on Queen $\mathrm{Mab}$ or the words that come as a harbinger of Mercutio's death do not sound as forcefully artificial as in Zeffirelli's adaptation.

Both Zeffirelli and Lurhmann design Mercutio's character in the way that opens up space for the reflection about their respective contemporary times. Zeffirelli places most emphasis on the relationship between Romeo and Mercutio, which, according to numerous critics, alludes to homosexuality and therefore provides evidence of the breaking of sexual taboo in 1960s' cinema[28]. In line with postmodern tendencies, Luhrmann eschews a sombre attitude in favour of entertainment and playing with genre conventions. His interpretation of Mercu- 
tio dressed up as a drag queen and taking LSD is just another mockery of the contemporary world, rather than a statement on the actual character himself [29].

This is also the way which determines the viewer's interpetation of how Luhrmann shapes the reality depicted in the whole film. Therefore, the ironic and tacky remains "outside", i.e. it never permeates into the "fabric" of Shakespeare's characters. This is exactly the way Pawel Łopatka interprets Lurman's 'camp approach' as the permanent feature of his work, which in William Shakespeare's Romeo + Juliet manifests itself only in the set and the props whereas: "The actors play with intensity but in all seriousness, without the pathos typical of camp behaviour, and at the same time, they do not let themselves get carried away in the obvious enchantment of the Shakespearean line." [30]

Both adaptations discussed here contain numerous shortcuts in terms of the support characters. However, only two of those might confuse the audience. The first of these is $\mathrm{Ze}$ ffirelli's choice to give up altogether on one of the smaller, yet essential parts, i.e. that of the Apothecary. Without him it is unclear where Romeo gets the poison from. Luhrmann, on the other hand, disposes with Friar John and instead introduces a messenger who does not deliver the letter on time. This is because Luhrmann does not fall for Shakespeare's story of the plague. In the same vein, Zeffirelli simply does not allow Romeo to meet Friar John, as they fail to meet each other on their way.

As a matter of fact, the Friar John thread in the play is not as clear for at least two reasons. Firstly, Romeo is promised by Friar Laurence that his messages will only be passed on by Friar Balthasar, not Friar John. Secondly, the idea of the plague raises considerable doubts of a logical nature. Nevertheless, Henryk Zbierski provides several arguments in defence of Shakespeare's choice. For instance, he argues that the messages have to be delivered in a hurry and Balthasar is simply not around. Somebody has to inform Romeo about what had happened and Friar John is both at hand and also from the same monastic order[31]. Additionally, the mistake made by Friar Laurence, i.e. sending an inappropriate messenger, serves as confirmation to the audience that it is he who is the protagonist doomed with hamartia. Zbierski highlights this point as a clear indication of Shakespeare's genius in plot design. The fact that a detail like this (the question of Friar Laurence) is frequently not elaborated sufficiently in Shakespeare's plays, forces the audience to read different meanings into the drama, i.e. opens space for its re-interpretation[32].

\section{Time and setting}

Shakespeare himself never went to Verona, yet he selected this city as the setting for his play. While he leaves the reader with just a few general remarks about the place (a street in Verona, the house of Capulet), Zeffirelli transforms it into a beautiful, green and romantic setting. The only off-putting element is the wall of the Capulet palace, whose shabbiness stands as a metaphor for the obstacle standing in the way of true love. As described by Shakespeare, it is pretty high and difficult to scale, although Romeo jumps over it "With love's light wings" [33] [Act II.2: p. 61].

Luhrmann's Verona becomes Verona Beach, while the Sycamore Grove turns into a deserted beach with the ruins of the theatre at its centre. The place is full of dirt, abuse, prostitution. Kitch has taken over every sphere of life, including religion. Verona Beach is a caricature of the contemporary world, the common denominator of what is stupidest and most laughable within it. In Zeffirelli's adaptation, the city of Verona serves as the theatre stage on which the drama of the lovers' tragedy plays out. In Luhrmann's film, however, Verona Beach plays one

[29] R. Jackson, op.cit., p. 89.

[30] P. Łopatka, Trzy sposoby na Szekspira [Three solutions to Shakespeare], "Kwartalnik Filmowy"

[Film Quarterly] 1999, no. 26-27, p. 201.

[31] H. Zbierski, op.cit., pp. 312-320.

[32] Ibidem, p. 321.

[33] W. Shakespeare, Romeo and Juliet, Act II.2: p. 61. 
of the most prominent parts in its own right, i.e. it provides the basis for the most contemporary adaptation in terms of the time and the setting. In this way, Paris, the ideal youth, finds himself on the cover of 'Time' magazine, while Friar Laurence has a big cross tattooed on his back, and a dingy snooker bar goes by the name 'Globe'. Luhrmann's adaptation is crammed with details from contemporary popular culture, although they do not trigger any special metaphorical meanings. They are merely there to evoke particular associations with contemporary reality, for example, the engagement ring that appears in Shakespeare's play is completely ignored by Zeffirelli, whereas Luhrmann features the ring in several instances as a hackneyed symbol of love.

As a punishment for killing Tybalt, Romeo is exiled to Mantua. Both cities, i.e. Verona and Mantua, actually come from the Italian piece written by Bandello, which in fact served as Shakespeare's inspiration. Nevertheless, the average contemporary reader associates these places only with Shakespeare's play, which is most probably down to his ingenious talent as a playwright and the renown that his play has acquired. Since Verona and Mantua lie 40 kilometres apart, Romeo can return from his exile quite quickly in order to be able to rest by the side of his beloved Juliet.

In Zeffirelli's adaptation, Mantua is not in fact a city in the strict sense of the word, i.e. the film neither presents the image of the place nor even a film decoration that could symbolise it. Romeo is simply exiled there and then returns. Luhrmann, on the other hand, features Mantua as a dusty desert town, whose suffocating atmosphere is both literal and metaphorical, as Romeo waits with bated breath for news from Verona Beach. Associations with yet another film are unavoidable here. Luhrmann draws

[34] W. Shakespeare, Romeo and Juliet, Act V.1: p. 123.

[35] Cf. H. Zbierski, op.cit., p. 287.

[36] P. Łopatka, op.cit., p. 200.

[37] Also covered by: P. Tatspaugh, op.cit., p. 142. inspiration from Agnieszka Holland's Total Eclipse (1995), mainly in terms of its visuals, but also because of it featuring the same actor. In both Holland's and Luhrmann's productions, the desert becomes the place of exploration, anticipation and quest. Romeo in exile resembles Arthur Rimbaud from Holland's film through the same image of the character smoking a cigarette and diligently jotting down his thoughts:
And all this day an unaccustom'd spirit
Lifts me above the ground with cheerful thoughts.
I dreamt my lady came and found me dead,
(Strange dream, that gives a dead man leave to think)
And breath'd such life with kisses in my lips
That I reviv'd and was an Emperor.
Ah me, how sweet is love itself possess'd
When but love's shadows are so rich in joy![34] [Act V.1: p. 123].

In Shakespeare's play, these words signal a premonition about inevitable fate; they herald tragic irony[35], whereas in Luhrmann's interpretation they turn into poetry and Romeo, the writer, becomes an artist. Paweł Łopatka confirms that the young Montecchi "is a poet who keeps noting everything down in a notebook" [36]. In this way, Luhrmann includes Romeo in the rank of the artists who seek their artistic inspiration in their own suffering.

Shakespeare set Romeo and Juliet in his times, which can easily be deduced from the Nurse's clumsy lines account of the earthquake. Zeffirelli sticks to the original time setting of the $16^{\text {th }}$ century and therefore dresses his characters in ornate Renaissance costumes (designed by Danilo Donati), as they glide around rooms reconstructed in the spirit of the Shakespearean era. Zeffirelli centres the whole scenery around Verona's main square along with its church. It is here that the most important scenes take place, i.e. the Prologue, Mercutio's death, Romeo and Juliet's wedding and, finally, their funeral processsion[37].

Luhrmann provides the audience with a completely different experience of time, which passes much more quickly due to the video-clip montage. Incidentally, Shakespeare's 
play also covers a markedly brief period of time, i.e. a mere five days. The lovers meet on Sunday, get married on Monday only to be separated on Wednesday and to die together on Thursday. According to Caroline F.E. Spurgeon, "Shakespeare saw the story, in its swift and tragic beauty, as an almost blinding flash of light, suddenly ignitied, and as swiftly quenched"[38]. The motif of light recurs in the original text of the play and therefore it is also frequently taken up by film adaptations. The light of dawn wakes the lovers in both films discussed here, just as torch light accompanies them inside the tomb. An element of light is also woven into the tragic dimension of their love, as summarised by Friar Laurence:

These violent delights have violent ends And in their triumph die, like fire and powder, Which, as they kiss, consume[39] [Act II.6: p. 78]

\section{Tragedy}

The question whether Romeo and Juliet is in fact a tragedy has been raised on numerous occasions. Although Shakespeare himself named his play as such, it has to be remembered that it was written in the 'non-tragedy' period of his early writing career. In 1594 Shakespeare was a thirty-year-old novice playwright and his most outstanding works and impressive tragedies were only to emerge seven years later. Romeo and Juliet was written before the onset of the 17 [th] century, i.e. before Shakespeare's most prolific period, which brought several tragedies one after another.

Obviously, the most vital arguments against categorising Romeo and Juliet as a tragedy are contained in the work itself. One of them is the fact that one-third of the dialogues are comedy lines. Moreover, comic characters, i.e. Mercutio and the Nurse, come across as the most skillfully designed. Finally, the actual tragic conflict remains external. Andrew Cecil Bradley confirms that Romeo and Juliet are not "torn by an inward struggle" [40], as opposed to the protagonists from the later tragedies such as Hamlet, Macbeth or Othello. Henryk Zbierski also notes that with Romeo and Juliet, it is hard to identify their hamartia, the fatal flaw of the lovers. Romeo and Juliet were to blame for not following their parents' orders, at least in Bandello's Italian prose and its English equivalent in the poem by Arthur Brooke[41], which both provided Shakespeare with inspiration. In his play, the fatal flaw does not take the same form as assumed by Aristotle. In Shakespeare's Romeo and Juliet, hamartia is scattered into little pieces shared by the support characters, i.e. Friar Laurence or Friar John. When Romeo cries (the famous line): "O I am fortune's fool" [42] [Act III.1: p. 84], he does not mean that he carries a heavy burden of the fatal flaw, but instead has fallen victim to ironic fate. In contrast to the classic rules of tragedy, he is not faced with the impossible choice between two equally important values. Romeo chooses Juliet and love; his is a happy choice of fulfilled love. Therefore it has to be concluded that the two lovers (both in Shakespeare's play and the film adaptations) are not characterised by the fatal flaw.

As argued by Auerbach: "Even Romeo's sudden falling in love with Juliet, for example, is almost fit for a comedy, and an almost unconscious development takes the characters in this play of love from child-like beginnings to a tragic climax"[43]. This line of argument leads to the conclusion that up to the scene of Mercutio's death, Romeo and Juliet develops in line with the features of a romantic comedy. Even more interestingly, while remaining a romantic comedy, this play also mocked the idea of romanticism at the same time. Mercutio laughs at Romeo's romantic trials and tribulations, comparing him to a protagonist from a Petrarch sonnet. However, at the same time the play does

[38] Cf. C.F.E. Spurgeon, Shakespeare's Imagery and What it Tells Us, Cambridge 2005, p. 312.

[39] W. Shakespeare, Romeo and Juliet, Act II.6: p. 78 .

[40] A.C. Bradley, Shakespearean Tragedy, London 1992, p. 12.

[41] H. Zbierski, op.cit., pp. 56-57.

[42] W. Shakespeare, Romeo and Juliet, Act III.1: p. 84.

[43] E. Auerbach, op.cit., p. 316. 
speak about love in the language of poetry, as a piece of a sonnet appears in Act One, Scene Five. This is the path followed by Zeffirelli in his adaptation, where up to the point of Mercutio's death, the film is a faithful reconstruction of Shakespeare's play. In other words, the screenwriters (Franco Brusati, Masolino D'Amico and Zeffirelli himself) took every effort to ensure that the dialogues in the adaptation are as witty as the original, but also as poetic and romantic.

Luhrmann, on the other hand, treats Shakespeare's lines daringly; he cuts them up and matches them up again, he adds new meaning through an unexpected juxtaposition with the images. In fact, in his adaptation, it is only Mercutio's and Nurse's comic lines that escape the ruthless scissors of the screenwriters (Baz Luhrmann himself and Craig Pearce). This kind of imbalance in favour of comic pieces again calls into question the tragedy in the original play. In Luhrmann's adaptation, comic effect is brought about not only through the dialogues themselves, but also because of the contrast with the images of contemporary reality. The world depicted is exaggerated and hence the humour also gains in irony. This comic effect does not stem merely from the lines, but also from a satirical perspective on kitsch, materialism and the superficiality of the modern era.

Due to fast editing, the beginning of William Shakespeare's Romeo + Juliet already contains several shots that summarise the whole film. Every frame is abundant in references to contemporary reality, i.e. billboards, kitsch figures of saints and adverts. Donald McAlpine, the photoprapher, made sure that there would be no single frame in the film that would lack dynamism, sparkle or blaze of colour. The kitsch reality clashes here with the $16^{\text {th-centu- }}$ ry text, but surprisingly, it works, even at the point where the line: "Give me my long sword

[44] W. Shakespeare, Romeo and Juliet, Act.I.1: p. 34 .

[45] H. Zbierski, op.cit., p. 55.

[46] As quoted by: Ibidem, p. 61.

[47] A. Żurowski, Czytając Szekspira [Reading Shakespeare], Łódź 1996, p. 269. ho." [44] [Act.I.1: p. 34] is followed by a pistol being pulled out.

There is only one untainted treasure in Luhrmann's adaptation, i.e. the love of the two protagonists. Although wearing jeans and $\mathrm{Ha}-$ waiian shirts, the lovers remain genuinely authentic when they clash with external reality. Their death bears features of pathos in exactly the way that Zeffirelli presents it. As concluded by Samuel Johnson, Romeo and Juliet is a drama with pathos, whose protagonists face suffering and death, but ultimately, their life proves to be a tragedy[45]. It has to be borne in mind that were it not for the letter that does not get delivered on time, or if Juliet's did not sleep for so long, the two lovers would be saved. There is an alternative for them, they could have lived happily ever after; it is only the fate that fails them. This is why Edward Chambers lists Romeo and Juliet among other love stories, together with those of Helen and Paris, Abelard and Heloise, Tristan and Isolde.[46]

Although Luhrmann's adaptation is teeming with pop MTV hits of the time, Romeo and Juliet's death is accompanied with the soundtrack that actually highlights their resemblance to their Shakespearean prototypes, as in the grave scene, where Leontyne Price sings Liebestod from Wagner's Tristan and Isolde finale. As a conseqence, despite the fact that the film draws profusely from contemporary images and music to provide an ironic context, it nevertheless manages to retain the purity of the two lovers, whose dead bodies are untouched by the corrupt world and will remain pure and innocent forever.

In spite of its tragic ending, it cannot be forgotten that Romeo and Juliet also has its bright side. The two protagonists are happy together and their love is fulfilled. Andrzej Z̈urowski puts it this way: "Romeo and Juliet is a bright kind of tragedy. It is a tragedy with optimism and joy at its heart" [47]. He goes on to say: "The world did kill Juliet and Romeo but did not manage to destroy them. It did not get them, they slipped right in time. They managed to fulfill the essence of their life. They succeeded at achieving 
the ultimate level of the sublimation of solitude, i.e. the solitude of being together" [48]. It is hard to say more than this, but Luhrmann manages to do so. After the scene of the protagonists' death, the audience is shown a retrospective of their happiest moments (the first meeting, the joy of their intimacy). The director suspends the ironic tone for a moment, only to come back to it in the next scene with the police, and the dead bodies wrapped in plastic bags carried away in an ambulance. Zeffirelli's adaptation does not make ironic comments about the contemporary reality and in this scene the funeral procession simply accompanies Romeo and Juliet to their final resting place.

Unparalleled wit and powers of observation make Shakespeare's language unique. His ambivalent attitude towards tradition and the rigid structure of the drama seems to confirm Shakespeare's genius, which to this day remains hard to embrace. By breaking with convention, favouring an episodic stucture, blending tragedy with comedy, Shakespeare must have been conscious of the risk he took, i.e. the fact that at any point the audience could turn their back on him and his work. Every time, though, Shakespeare decided to take up the challenge, like those who decided to make film adaptations based on his plays. Each technical device the adaptors selected could have turned out to be a wonderful novelty or a total disaster. The strength of both Zeffirelli's and Luhrman's adaptation is the emphasis on love and youth, which thanks to their director's skill, is perfectly in tune with the spirit of their respective times.

Translated by Aleksandra Oszmiańska-Pagett and Rob Pagett
B I B L I O G R A P H Y

Auerbach E., Mimesis, The Representation of Reality in Western Literature, Princeton 2003

Bradley A.C., Shakespearean Tragedy, London 1992

Buhler S.M., Shakespeare in the Cinema, Ocular Proof, New York 2002

Coleridge S.T., Coleridge's Lectures on Shakespeare and Other Poets and Dramatists. The Seventh Lecture, ed. Ernest Rys, London 1914

Hankins J.E., Introduction, [in:] W. Shakespeare, Romeo and Juliet, New York, London 1970

Helman A., Przemoc i nostalgia $w$ filmie gangsterskim [Violence and nostalgia in the gangster film], in: Kino gatunków wczoraj i dziś [Genre cinema now and in the past], ed. K. Loska, Kraków 1998

Jackson R., Shakespeare and the English Speaking Cinema, Oxford 2014

Łopatka P., Trzy sposoby na Szekspira [Three solutions to Shakespeare], "Kwartalnik Filmowy" [Film Quarterly] 1999, no. 26-27

Shakespeare W., Macbeth, Cambridge 1925

Shakespeare W., Romeo and Juliet, London 1994

Spurgeon C.F.E., Shakespeare's Imagery and What it Tells Us, Cambridge 2005

Stachówna G., O melodramacie filmowym [On film melodrama], [in:] Kino gatunków wczoraj i dziś [Genre cinema now and in the past], ed. K. Loska, Kraków 1998

Tatspaugh P., The Tragedies of Love on Film, [in:] The Cambridge Companion to Shakespeare on Film, ed. R. Jackson, Cambridge 2000

Zakens P., Szekspirowanie po ekranie [Shakespearean screen], [in:] Szkice z poetyki filmu [Essays on film poetics], ed. M. Hendrykowski, Poznań 1995

Zbierski H., Droga do Werony. Studium historycznoliterackie. „Romeo i Julia” Szekspira [En route to Verona: historical and literaty study of Shakespeare's Romeo and Juliet], Poznań 1966

Żurowski A., Czytajac Szekspira [Reading Shakespeare], Łódź 1996

[48] Ibidem, p. 271. 